\title{
Metrical Relations Between Siamanto's Poetry and Medieval Armenian Verse
}

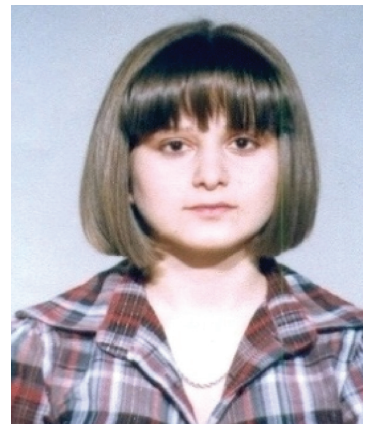

Karina Asatryan
$\mathrm{T}^{\mathrm{t}}$ is an undeniable fact that the poetry of great Armenian poet Siamanto (Atom Yarjanian) in its constructional form is tuned according to the new poetical system of free verse that was widespread in the literature at the beginning of the $20^{\text {th }}$ century. Siamanto's poetry, however, is also based on a variety of metrical forms typical of old and medieval Armenian verse. Creating his poetry in accordance with the main constructional norms of free verse, the author combined poetical meters of Armenian medieval lyrics with numerous stylistic elements of modern poetry.

In Armenian literature the first free version texts are found in historiography, many pages of which look like rhythmical-musical poems. Such artistic-descriptive fragments of the $5^{\text {th }}$ century Armenian historiography can be described as having a rhythm of free verse. "Histories of Armenia" by Agathangelos, Pavstos Buzand, M. Khorenatsi testify to this fact. The same can be said about the style of exposition and poetical images that we find in "Sebeos's history" of the $7^{\text {th }}$ century. The texts of Armenian spiritual songs - sharakans which have become an important and indispensable part of Armenian spiritual literature since the $5^{\text {th }}$ century also possess a free construction. Over the centuries the already created sharakans underwent certain modifications, and new ones were created. Still later, these texts served as a basis for separate literary poetic works. The construction of spiritual verses is closely connected with their content, namely, with the so-called "universal plots" of the Bible and spiritual music. Due to this connection the spiritual verses are constructed according to definite structural regularities. Sharakans as a form of ecclesiastic music don't refer to rhyme in which the rhythmic aspect becomes an uneven arrangement of syllables and emphasizes certain accents, i.e. their construction is rhythmically free.

In later centuries (following the birth of sharakans) ecclesiastical spiritual lyricism gradually inherited the easiness of form typical of Armenian national mindset and mentality and artistic taste. It also made wide use of constructional potentialities of the socalled "secular poetry". Many constructional peculiarities of Armenian folklore served as a source for not only Armenian ecclesiastical lyrics but Siamanto's poetry as well.

Siamanto's poems may be conditionally divided into two groups. The first one includes those poems that don't adhere to any constructional canons ("Heroically", "Armenian Children"). The second group of poems remains within boundaries of creative free style, at the same time containing lines of metrical verse ("Torches of Spiritual Behavior and Hope", "Bloody News from My Friend", "The Homeland's Invitation", "Saint Mesrop"). The latter poems belong to blank verse and present metrical canons of Armenian syllabic verse. The blank verse of Siamanto, unlike the Armenian medieval poetry, isn't rhymed. However, internal rhyming (assonance and consonance so typical 
of medieval spiritual and secular lyricism) is evident in some of his verses.

Siamanto's poetry is so spontaneous that it may need no rhyming at all although his selective rhyming adds to the beauty of his poems. His thoughts are completed and summed up by rhyming in general and paragraphing in particular, which, although meaningfully important, sometimes give way to the "imaginative set", i.e. the imaginative environment. What is more, the melodiousness of lines is abundantly charged with the author's thoughts and boundless and tempestuous flow of emotions thus giving tribute to the modern literary flow - symbolism, at the same time adopting the poetical metrical form typical of Armenian ecclesiastical lyrics (Hayrenik 1955:21).

Speaking about the metrical relations of Armenian epical verse and the verse of Siamanto we should mark that the majority of his poems have identical features with the "historical songs" - the heritage of M. Khorenatsi. These songs first of all present epical images which are put in motion or action by plot structure. The epical verse is abundant with other imaginative details in which the rhythm of lines is constructed with and by means of impetuous and, on the contrary, slow action of the images. Parallel to emotionality and imaginativeness of epical verse, Siamanto's poetical images are endowed with additional psychological and dramatic tensions. Some fragments of his epical verse are constructed and presented in the form of a complete syntactical unit - sentence, in which pauses are marked in accordance with the wholeness and intonational-pronunciational divisions of combinations of words and phrases.

The expressiveness of poetical speech is signified by phonetic iteration which in ancient poetry, especially in the medieval Armenian poetry, had a particular role. Owing to rhythmical vibration of phonetic iteration the speech develops in a more dynamic way. Besides expressiveness, the harmony of phonetic iteration is also achieved through musical images in some big fragments of verse. ${ }^{1}$ In Siamanto's poetry phonetic repetition is a means through which to underline rhythmical vibration and associate different shades of meaning of words.

Siamanto not only used poetical meter typical of medieval Armenian poetry but also developed it according to his creative style. This is especially evident in his poems created in early $20^{\text {th }}$ century. His poetical prose, his voluminous verse presented the bloody, dramatic facts and events of the epoch of Armenian tragedy through a profound analysis of the psychological emotions of the author ("Bloody News from My Friend"). As all his other creations, the free verse poetry of this period displays peculiarities of Armenian canonical verse combined with new structural forms of contemporary poetry. We mean, in particular, the poems "Bloody News from My Friend", "Torches of Spiritual Behavior and Hope", "The Homeland's Invitation", "Saint Mesrop".

Here is "The Prayer of Navasart for Goddess Anahid":

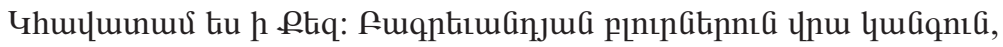

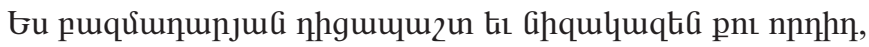

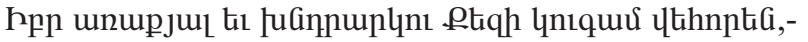

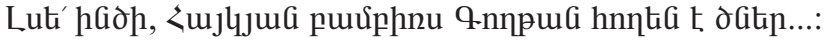

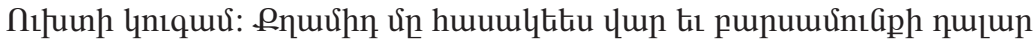

nuuntip hảtınhu, 


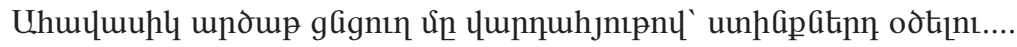

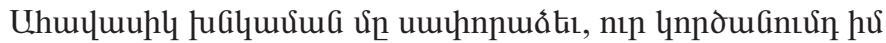
ungniapn ¿ lu tiu 1 lugh....

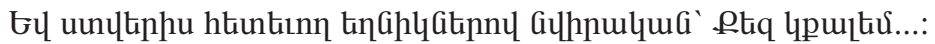

I believe in You. Standing firm on the hills of Bakrevant, I, a pagan of many centuries and your son armed with arrows, As a messenger and implorer I come to You grandly, Hear me, my Haigian castanets were born from the Koltan earth...

I come as a pilgrim. Wearing a chlamys longer than my height and green twigs in my hand as wands,

Here is a silver pot with rose essence to anoint your breasts...

Here is an urn-shaped incense dish where I cried for your ruin with my tears...

I walk toward You with precious roes following my shadow...

Considering versifcational relations between the poetry of Siamanto and medieval Armenian poems, namely the poetical meters abundant in sharakans, it can be stated that the iambic sixteen-syllabic form $(4+4+4+4)$ is common for both. According to E.Jrbashian Armenian versification "is an important realization of the concept of compound two-feet close foot" (Jrbashian 1973:308). Two iambic feet consist of one compound foot. The iambic sixteen-syllabic form is four compound feet. This form is found in such poems by Siamanto as "The Song of the Knight", "Expiation", "Brother to His Brother", "The Young Wife's Dream", "Entreaty of the Armenian Fields", "The prayer of Navasart for Goddess Anahid". The same form is observed in medieval Armenian poems of N.Shnorhali, H.Pluz, K.Erznkatsi, H.Tlkurantsi.

For example:

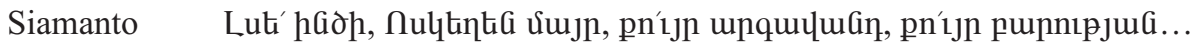

$$
(4+4+4+4)
$$

Hear me, Golden mother, fertile sister, sister of goodness...

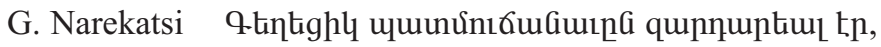

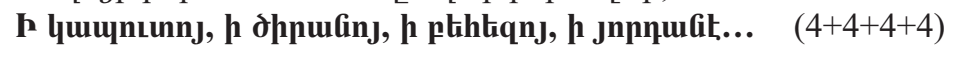

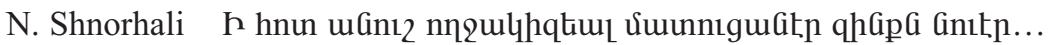

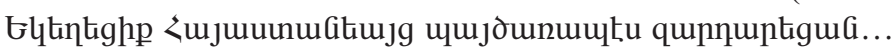

$(4+4+4+4)$

$(4+4+4+4)$

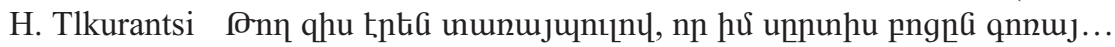

$(4+4+4+4)$

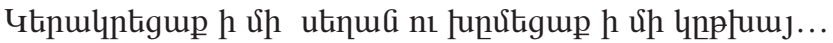

$(4+4+4+4)$ 
Similarly, the source of the iambic twelve-syllabic form $4+4+4$ used by Siamanto is the Armenian traditional versification. This form is equally typical of Siamanto's "A Handful of Ash" and "Saint Mesrop", P.Khapantsi's (a medieval author) poems and sharakan.

For example:

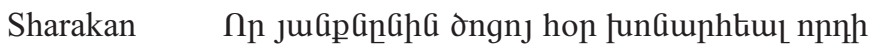

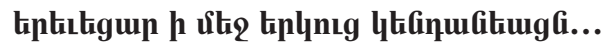

Siamanto Gu hptintig hughn lumñ in gnptiupun...

I, reaper of wheat longing for your fiery bread... $\quad(4+4+4)$

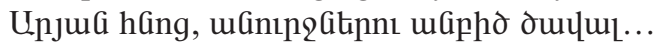

Furnace of blood, spotless expansion of visions...

Moreover, in "Saint Mesrop" Siamanto used a variation of the above mentioned form - two compound feet with 7+5, 5+7 constructions, which are found in sharakans and in some medieval poets' works. ${ }^{4}$ Two other poetical forms used in Armenian medieval poetry and then inherited by Siamanto and representatives of contemporary literature are iambic fifteen-syllabic form (four compound feet) with one anapest, $4+4+4+3$ and iambic fourteen-syllabic form (four compound feet) with two anapests, $4+3+4+3$. These forms are observed in Siamanto's "The Vintage" and "The Song of the Knight". The traditional form most frequently used by Siamanto in different positions in "The Homeland's Invitation" and "Saint Mesrop" is the iambic eleven-syllabic form (three compound feet) with one anapest, $4+4+3$. With parallel frequency this form is present in the poem-songs of medieval authors G.Narekatsi, K.Erznkatsi, G.Akhtamaretsi, N.Hovnatan. The two other types of eleven-syllabic form used in "Saint Mesrop" are $6+5,5+6$. The same types with nearly the same arrangement of feet are found in medieval poems of N.Hovnatan and P.Dpir.

For example:

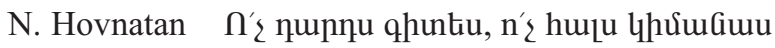

ก'乏 hGum $\Phi$ quatiu, n's tiptiunn pugiuu...

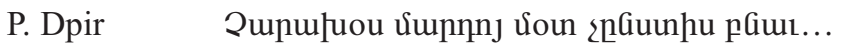

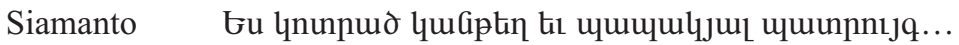

I, broken lantern and thirsty wick...

In general in all of Siamanto's works the versificational constructions are conditioned by textual content. In G.Narekatsi's poems the five-syllabic compound feet is metrically quite free in exposition and is used in works presenting tempest of thought. 5

The similar phenomenon is observed in Siamanto's poems. For example in the fivesyllabic compound feet found in the verses of the collection "Bloody News from My Friend" the reality seems to be represented by "a man in agony". 6 The poems are rhyth- 
mical and naturally more imaginative and expressive. As to the twenty-syllabic form (four compound feet) containing both iambic and anapest feet $(5+5+5+5)$ and initially used by G. Narekatsi, in Siamanto's "The Prayer of Navasart for Goddess Anahid" ,"The Blind" and "The Mulberry tree" it changed into a four-syllabic (five compound feet) $4+4+4+4+4$ one with iambic feet and four-syllabic (six compound feet) $4+4+4+4+4+4$. In "Saint Mesrop" we come across the ten-syllabic form $2+8$ and another type of ten-syllabic form, the 6+4 construction with nearly the same arrangement of feet as in sharakans. The iambic thirteen-syllabic form (three compound feet) with one anapest $(4+4+5,5+4+4)$ is still another Armenian medieval versificational form used by Siamanto.

For example:

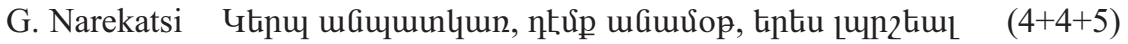

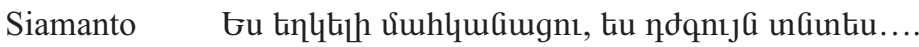

I, pitiful mortal, I, pale steward...

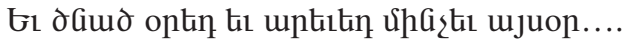

And from the day you were born, and from your sun until today...

The thirteen-syllabic forms $5+3+5$ and $5+5+3$ is a characteristic feature of both medieval poems and "Saint Mesrop".

For example:

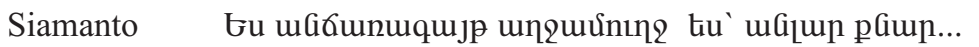

I, ray-less dusk, wire-less lyre...

$(5+3+5)$

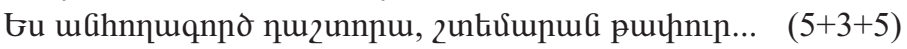

I, non-farming field man, wine-distributing warehouse...

Last but not the least nine $(5+4,4+5)$, eight $(5+3,4+4)$ and seven $(4+3)$ syllabic forms (two compound feet) are usages in Siamanto's poetry. These forms make certain fragments of the poem more dynamic.

For example:

Siamanto onuph' unpjnıp, puich' pupánıGap,

Gupnnnıpjuag uGiltíns quunun...

$(4+4)$

Fountain of speech, height of reason,

Endless summit of abilities...

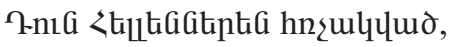

Utiduunpunnu Ulynuर्un...

You, declared by the Hellens

As grand-titled Academic... 
The line rows with different metrical forms that follow each other help the poet to express the drama of the restless soul, its outbursts of seethe emotions. The imagery conditions changeable forms of expression and free syntactical constructions and each time is presented with new artistic force. The same process is observed in Narekatsi's poetry.

Summing up whatever has been discussed above we can say that creating his free verse poetry, expressing his wrath of soul, his gust of pain, his unbounded love by streamy speech, the great Armenian poet Siamanto remained constant to his literary roots - he developed significantly Armenian metrical form used by his literary ancestors.

\section{Notes:}

1. Repetitions have an artistic and metrical meaning also in many medieval Armenian clerical lyric poems (G.Narekatsi, N.Shnorhali). In Narekatsi's poems-gandzes, taghs and in his famous "Narek" ("Book of Lament") the art of phonetic iteration attains its perfection. G. Narekatsi seethes poetical lines with coloured and vocal surf of assonance and consonance. He managed to create a poetical symphony through mixed meter lines without rhyme. N.Shnorhali successfully used phonetic repetition to emphasize the spiritual content of clerical songs and sharakans.

2. Literary scholars H.Tamrazian and M.Mkrian have touched upon such topics as artistic modes of representation and forms of stylization in G.Narekatsi's and Siamanto's works. H.Rshtuni discussed poetical forms used by Siamanto in his monograph "Siamanto" (Tamrazian 1969).

3. This and other translations of Siamanto's poems presented in the paper belong to Shant Norashkharian.

4. Medieval Armenian poets H.Tlkurantsi, Z.Gnuneants and G.Akhtamaretsi are meant.

5. The five-syllabic two compound feet form $5+5$ is not typical of Siamanto's poetry although we come across it in "Saint Mesrop". In poetical form and thematic content this work reminds of a medieval poem. Both medieval poets (G.Narekatsi, N.Shnorhali) and Siamanto used this form to criticize human faults and to glorify God.

6. The fifteen-syllabic form (three compound feet) $5+5+5$ with both iamb and anapest feet was used by G. Narekatsi in the $10^{\text {th }}$ century. However, this construction is not typical of Siamanto's blank verse.

\section{References:}

1. Jrbashian, E. (1972) The Theory of Literature. Yerevan: Yerevan State University.

2. Mkrian, M. (1988) Works. Vol. 2. Yerevan: Yerevan State University.

3. Rshtuni, H. (1970) Siamanto. Yerevan: Hayastan Publishers.

4. Siamanto. Life and Work. (1955) N4. Boston: Hayrenik. 
5. Tamrazian, H. (1969) Siamanto. Yerevan: Hayastan Publishers.

6. http://www.umd.umich.edu/dept/armenian/literatu/

\section{Literature:}

1. Siamanto and Varouzhan (1979) // Library of Armenian Classics. Yerevan: Sovetakan grogh.

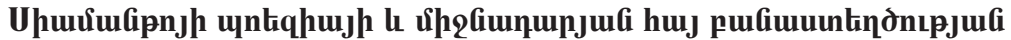

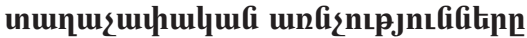

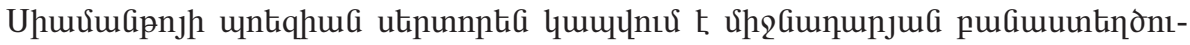

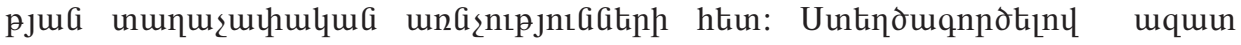

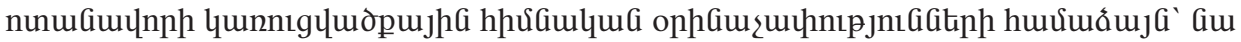

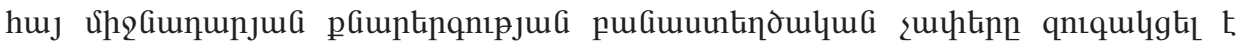

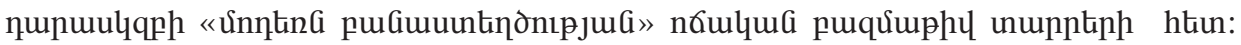

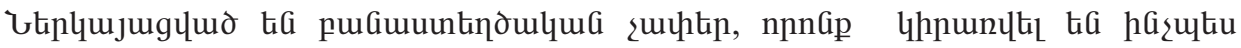

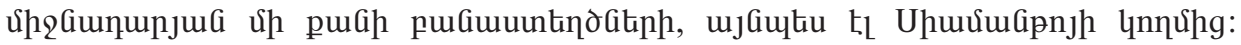

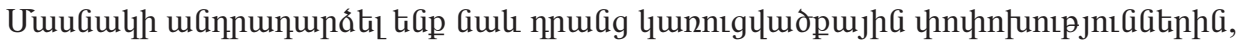
nnnGip luunuptį t. UhưumGipng: 